\title{
Problemy rynku mangi w Polsce
}

DOI: $10.12775 /$ TSB.2013.004

STRESZCZEniE: Manga w Polsce jest obecna od 1997 r. i przybyła na fali popularności anime w telewizji. To jedno z najbardziej rozpoznawalnych produktów japońskiej popkultury na świecie. Pierwszym wydawnictwem, jakie zajęło się publikacją tego gatunku komiksu w naszym kraju, było Japonica Polonica Fantastica (JPF), do dziś największa i najważniejsza oficyna spośród pięciu funkcjonujących na rynku. Pierwszym czasopismem polskim, które poświęcono mandze, był magazyn „Kawaii”. W Polsce japoński komiks budzi wiele kontrowersji, przez co spotyka się ze specyficznymi problemami na rynku, do których należy dystrybucja, postęp technologiczny, powszechnie panujące stereotypy i kłopoty w zdobyciu licencji.

SŁOWA KLUCzowE: komiks, manga, rynek wydawniczy.

\section{Geneza i początki mangi}

Omiks japoński, czyli manga razem z anime, należą do najbardziej Mrozpoznawalnych produktów japońskiej popkultury na świecie. Budzą w Polsce wiele kontrowersji i mają niemalże tyle samo zwolenników co przeciwników. Przez jednych manga jest doceniana, inni zaś posądzają ją

* Studentka I roku uzupełniających studiów magisterskich z zakresu zarządzania informacją i bibliologii w Instytucie Informacji Naukowej i Bibliologii Uniwersytetu Mikołaja Kopernika w Toruniu. 
o przekazywanie treści gorszących i brak pozytywnych wartości. Tradycja komiksu, szczególnie satyrycznego, sięga w Japonii czasów starożytnych. Na ścianach świątyni Hōryūji, a także wśród zabytków zgromadzonych w skarbcu Shōsōin wybudowanym w epoce Nara (710-780) można znaleźć satyryczne rysunki, które najprawdopodobniej były inspiracją dla najsłynniejszego, przednowożytnego zbioru satyrycznych szkiców, czyli Chōjū giga, przypisywanych kapłanowi Tobie'1.

W średniowieczu (VIII w.) powstały iluminowane zwoje, nazywane emakimono, w skrócie emaki ( $e$ - obraz, maku - zwijać, mono - rzecz), które są uważane za „prakomiksy”. Ich celem było odzwierciedlanie życia dworu, ilustrowały także sceny religijne, literackie i mitologiczne. Były to utwory malarsko-literackie w postaci zwojów papieru nawijanych na wałki z drewna. Zawierały obrazki wraz z ich komentarzem literackim, tworzące fabułę powieści ${ }^{2}$. Perspektywa nie była zamykana w jednym kadrze, ale zwielokrotniana ${ }^{3}$. Dawały one możliwość opowiedzenia długich historii, były niezwykle cenne oraz delikatne. Cztery z nich zostały sklasyfikowane jako skarb narodowy, m.in Genji monogatari emaki (ilustrowane zwoje do opowieści o księciu Genjim) ${ }^{4}$.

Podczas bujnego i szybkiego rozkwitu Edo (dzisiejsze Tokio) najbardziej upowszechniły się dwa typy dzieł: książki-poradniki, zwane shomotsu, oraz książki, które mały służyć rozrywce - sōshi. Do tych ostatnich zaliczano również drzeworyty $u k i y o-e^{5}$.

W epoce Edo (1603-1868) dominowała twórczość malarska i drzeworytnicza zwana ukiyo-e. Nazwa tej szkoły jest tłumaczona jako „świat, który przemija” (ukiyo) lub „obrazy dryfującego świata”. W WVII w. sztuka ta zaczęła wyrażać hedonistyczne przyjemności związane z używaniem życia. Ukiyo-e stały się jedną z pierwszych w Japonii form kultury popularnej ze względu na niskie koszty produkcji i masowość. W XVIII i w pierwszej połowie XIX w. japońska kultura masowa przeżywała okres

1 P. Varley, Kultura japońska, Kraków 2006, s. 337.

2 M. Jaworski, Japońska inwazja (pop) kulturowa? Kontrowersje wokół japońskich komiksów i filmów animowanych w Polsce, „Edukacja Otwarta” 2002, nr 1/2, s. 121-122.

3 B. Koyama-Richard, Manga 1000 lat historii, Warszawa 2008, s. 9.

4 Tamże, s. 10.

5 Tamże, s. 38-40.

${ }^{6}$ M. Studzińska, Skąd wzięła się manga? O niepohamowanych obrazach Katsushiki Hokusaia, „Otaku” 2008, nr 5 (13), s. 43. 
swojego największego rozkwitu. Powstawały biblioteki, zarówno książki, jak i drzeworyty powielano często w kilku tysiącach egzemplarzy ${ }^{7}$. Najczęściej podejmowanymi tematami ukiyo-e były miejskie i wiejskie scenki rodzajowe, korowody pątników i podróżników, krajobrazy, wątki i postacie związane z teatrem kabuki, dzielnicami rozrywki itd. ${ }^{8}$ Pełniły one funkcję reklam, stanowiły środek komunikacji, służyły dzieciom do nauki czytania i pisania9.

Wielkim artystą drzeworytnikiem był Katsushika Hokusai (1760-1849). W wieku osiemnastu lat przystał do pracowni twórcy drzeworytów Katsukawy Shunshi i zadebiutował serią portretów aktorów ${ }^{10}$. W jego twórczości dominował realizm, nie brak jednak motywów fantastycznych czy mitologicznych. Jako pierwszy użył terminu manga, na który składają się dwa chińskie ideogramy: man - „mimowolny”, „poza sobą”, oraz ga - „obraz”. Połączone, tworzą słowo, które w wolnym tłumaczeniu oznacza „niepohamowane obrazy”"11. Obecnie znaczenie tego terminu jest szersze, obejmuje oprócz komiksu również karykaturę, powieść obrazkową i film animowany ${ }^{12}$.

Hokusai prowadził studia nad malarstwem japońskim, chińskim i europejskim, czerpiąc z nich inspirację, aż stworzył swój własny, niepowtarzalny styl. Wprowadził też pewien specyficzny zabieg w przedstawianiu postaci lub zjawisk w różnych etapach ruchu, co wywołało efekt przypominający klatkę filmu animowanego ${ }^{13}$. Aktywnie tworzył aż do śmierci w wieku 89 lat $^{14}$. Za najważniejszy uważa się cykl ze szkicami Manga, serie „Trzydzieści Sześć Widoków Góry Fuji”, „Podróż do Wodospadów w Różnych Prowincjach" oraz portrety pięknych kobiet (bijinga), ilustracje do popularnych powieści yomihon, obrazy przedstawiające zapaśników sumo (sumo-e) oraz album Sto widoków góry Fuji. Manga to szkicowniki z przykładami rysunków ludzi i elementów świata realnego, lecz również

7 M. Taniguchi, Manga, czyli jak mistrz Hokusai rysunku nauczał, [w:] Świat z papieru i stali - okruchy Japonii, pod red. M. Taniguchi, A. Watanuki, Warszawa 2006, s. 18.

8 Tamże, s. 16.

9 B. Koyama-Richard, dz. cyt., s. 38.

10 Tamże, s. 64.

11 M. Studzińska, dz. cyt., s. 41.

12 A. Materne, Manga japońska jako przejaw zderzenia kultur, „Pedagogika Społeczna" 2007, nr 1, s. 92.

${ }^{13}$ M. Studzińska, dz. cyt., s. 41.

14 P. Varley, dz. cyt., s. 220. 
postacie z mitów, legend. Miała służyć jako podręcznik rysunku, liczyła 15 tomów, pierwszy został wydany w 1814 r., a ostatni w 1878 r., wiele lat po śmierci artysty.

Odbiorcami Mangi zostali głównie japońscy mieszczanie, ale także szlachetnie urodzeni. Prace Hokusaia stały się bardzo popularne na Zachodzie, a niektóre z nich cieszą się do dziś takim samym uznaniem jak dzieła europejskich twórców. Paul Varley zwraca uwagę, że przypadek Hokusaia bardzo dobrze ilustruje wymianę kulturalną: japoński artysta czerpał z osiągnięć Zachodu, którego twórczość, tak jak i innych artystów ukiyo-e, była równocześnie źródłem nowej i egzotycznej inspiracji dla francuskich impresjonistów i innych zachodnich artystów do końca XIX w. ${ }^{15}$

Termin manga wyszedł z użycia pod koniec XIX w. Dla nazwania karykatur bądź humorystycznych obrazków stosowano wówczas starsze określenia, jak giga czy Tobae. Ponownie zaczął funkcjonować powszechnie dopiero na przełomie lat 20. i 30. XX w., gdy Japonia porzuciła politykę izolacji i ponownie otworzyła się na Zachód. Dotarł tam wówczas amerykański komiks, który miał duży wpływ na powstanie mangi. Japończycy zaczęli publikować w gazetach codziennych pierwsze stripy komiksowe ${ }^{16}$. Gwałtowny rozwój komiksu nastąpił w latach 50., kiedy to zamknięto kwaterę główną amerykańskich władz okupacyjnych i Japonia uzyskała pełną swobodę polityczną ${ }^{17}$. W dużej mierze powielano jednak tylko amerykańskie rozwiązania i pomysły. Głównym motorem rozwoju mangi były masowe migracje ludności wiejskiej do miast w poszukiwaniu pracy. Prości ludzie, najczęściej niewykształceni robotnicy fabryczni, znaleźli w niej źródło taniej rozrywki ${ }^{18}$. Podczas gdy od lat 50. popularność komiksów w Stanach spadała, ze względu na konkurencję

15 Tamże, s. 221.

16 A. Materne, dz. cyt., s. 92. Strip (pasek) to krótka forma komiksowa publikowana pierwotnie w gazetach codziennych, zawierająca od dwóch do sześciu kadrów. W Ameryce stosuje się na jej określenie termin comic strip. Por. Komiks. Formaty. W: Wikipedia. Wolna Encyklopedia [on-line] [dostęp 31 marca 2013]. Dostępny w World Wide Web: http://pl.wikipedia.org/wiki/Komiks\#Formaty; Comic strip. W: Wikipedia. The Free Encyclopedia [on-line] [dostęp 31 marca 2013]. Dostępny w World Wide Web: http:// en.wikipedia.org/wiki/Comic_strip.

17 M. Szafrańska, Manga - komiks z Dalekiego Wschodu, „Acta Universitatis Wratislaviensis. Literatura i Kultura Popularna” 2006, s. 150-151.

18 A. Materne, dz. cyt., s. 92. 
ze strony telewizji, w Japonii w tym samym czasie manga przechodziła prawdziwy „boom”. W 1980 r. komiksy stanowiły 27\% japońskiej produkcji wydawniczej, czyli 1,8 mld egzemplarzy ${ }^{19}$.

\section{Wspólczesna manga}

Mangę, w dzisiejszym tego słowa znaczeniu, zawdzięczamy Osamu Tezuce, zwanemu „bogiem mangi” (manga-no kami sama) ${ }^{20}$. Tezuka urodził się 3 listopada 1928 r. w Osace. Dzięki jego pracom komiksy awansowały do roli jednego z podstawowych elementów japońskiej popkultury ${ }^{21}$. Połączył on wcześniejszą japońską tradycję z wpływami i naleciałościami z dzieł zagranicznych i stworzył oryginalny styl, który stał się mangowym kanonem rysowania. Wprowadził do komiksu kinematograficzną narrację, dynamiczne ujęcia kadrów i porzucił sztywną strukturę przedstawiania treści. Stosował zmienne ujęcia, różnorodne plany i wykorzystywał w swych rysunkach sposoby służące do uzyskania dramatycznych efektów. Zerwał z tradycyjnym trzy- lub czteropoziomowym dzieleniem strony na rysunki i wprowadził absolutną dowolność w ustawieniu poszczególnych kadrów. Korzystał z jedno- lub dwustronicowych kadrów, których wcześniej nie stosowano ${ }^{22}$. Stworzył charakterystyczny sposób ukazywania postaci: drobna twarz z umownie zaznaczonymi ustami i nosami postaci, duże oczy - które Tezuka zapożyczył od Walta Disneya - oraz podkreślanie dziewczęcych atrybutów. Postawił przede wszystkim na wiarygodność postaci, co osiągnął, starając się oddać jak najwierniej ich emocje i wewnętrzne rozterki. Była to nowość w ówczesnych światowych komiksach ${ }^{23}$. Pierwszą mangą, dzięki

19 P. Varley, dz. cyt., s. 337-338.

20 A. Czaplińska, Fandom mangi $i$ anime $w$ Polsce [praca zaliczeniowa z przedmiotu kultura popularna i masowa w Polsce napisana pod kierunkiem dr. Tomasza Marciniaka, Toruń 2006] [on-line]. Zeszyty komiksowe - Składnica [dostęp 31 marca 2013]. Dostępny w World Wide Web: http://www.zeszytykomiksowe.org/skladnica/ czaplinska2006.pdf.

21 T. Gawroński 'Mr Gato', Bóg mangi Osamu Tezuka, „Kawaii” 2000, nr 1 (23), s. 18-19.

${ }^{22}$ R. Rojek, Nie wszystek umrę - uczniowie Tezuki Osamu, [w:] Świat z papieru i stali - okruchy Japonii..., s. 168.

23 T. Gawroński 'Mr Gato', dz. cyt., s. 18-19. 
której zyskał popularność, był Shin Takarajima (na podstawie historii Shichimy Saikai), który sprzedał się w ogromnym jak na owe czasy nakładzie 400 tys. egzemplarzy ${ }^{24}$. Jego dorobek został opublikowany przez wydawnictwo Kodansha i zawiera około 600 tytułów zawartych w 400 tomach $^{25}$. Były one publikowane m.in. w USA, Kanadzie, Francji, Hiszpanii, Niemczech, Polsce, Indonezji, Korei, we Włoszech i na Tajwanie ${ }^{26}$. Wśród jego najbardziej znanych dzieł można wymienić:

- Jungle taitei - 1950 r., w Polsce znana jest jego wersja animowana Biały lew Kimba,

- Tetsuwan Atom - 1951-1968 w „Shonen”, za granicą znany jako Astro Boy,

- Raibon-no kishi - 1953-1956, w „Shojo Club”, w Polsce wersja animowana pod tytułem Czopi i księżniczka oraz Przygody księżniczki. Była to jedna z pierwszych publikacji przeznaczonych głównie dla dziewcząt.

Osamu Tezuka był także autorem pierwszych filmów animowanych ${ }^{27}$. Są one znane pod popularną nazwą anime - słowo to pochodzi od angielskiego animation i oznacza film animowany lub od francuskiego animé (animowany) bądź les dessins animés (animowane obrazy) ${ }^{28}$. Tezuka stworzył na podstawie swoich tytułów dwie ważne serie anime. Pierwszą był słynny czarno-biały serial rysunkowy pod tytułem Tetsuwan Atom (Astro Boy). W 2009 r. powstała nowa, animowana wersja tego dzieła z użyciem nowoczesnych technik komputerowych i cyfrowych. Drugą była pierwsza w Japonii kolorowa seria rysunkowa - Jungle Taitei ${ }^{29}$. Do 1972 r. Tezuka adaptował swoje największe mangi na wersję anime, zapoczątkowując tym samym jego niezwykłą popularność w Japonii

24 Tamże.

25 K. Kotowska, Manga - japoński komiks a kultura Zachodu, „Biuletyn EBIB” [on-line] 2010 nr 9 (118) [dostęp 31 marca 2013]. Dostępny w World Wide Web: http:// www.nowyebib.info/2010/118/a.php?kotowska.

${ }^{26}$ A. i K. Watanuki, Tezuka Osamu - ojciec mangi, [w:] Świat z papieru i stali - okruchy Japonii..., s. 162.

27 M. Jaworski, dz. cyt., s. 122-123.

28 Por. Anime. W: Kompendium mangowe [on-line] [dostęp 31 marca 2013]. Dostępny w World Wide Web: http://kompendium.mangowe.pl/Hasla/anime/.

${ }_{29}$ Piyotoru, Manga i anime [on-line]. Gildia Kultury Dalekowschodniej [dostęp 31 marca 2013]. Dostępny w World Wide Web: http://www.manga.gildia.pl/publicystyka/manga_anime. 
oraz charakterystyczny związek tych dwóch nośników, polegający na ekranizacji popularnych komiksów.

Obecnie w Japonii manga i anime są jednym z najpopularniejszych elementów kultury masowej ${ }^{30}$. Mangi są drukowane fragmentami w tygodnikach (np. „Shōnen Jump”) lub miesięcznikach, a później przenoszone do wersji tomikowej. Aż jedna trzecia rocznego zużycia papieru jest przeznaczona na potrzeby tego przemysłu ${ }^{31}$. W ciągu roku ukazuje się około 260 tytułów w formie czasopism i książek, co stanowi około 40\% rynku wydawniczego japońskiego i około 1,5 mld nakładu ${ }^{32}$. Charakterystyczne cechy mangi to druk w czerni i bieli oraz czytanie od prawej do lewej strony. Zazwyczaj fabuła jest bardzo złożona, uwypukla się w niej uczucia i przeżycia postaci.

Manga porusza bardzo różnorodne tematy, a jej treść zależy od wieku i płci czytelników. Jej główne kategorie to:

- Shonen - dla chłopców, skoncentrowane na akcji i przygodzie, np. Naruto;

- Shojo - dla dziewcząt, koncentrują się na emocjach bohaterów, postacie często są nadmiernie „uślicznione”, np. Kamikaze Kaito Jeanie;

- Josei - (redisu bądź redikomi) dla starszych nastolatek i młodych kobiet, np. Suppli;

- Seijn - (dorosły lub erotyczny) tytuł erotyczny;

- Seinen - dla pełnoletnich mężczyzn, o poważniejszej problematyce (np. wchodzenie w dorosłe lub zawodowe życie), np. Akira, Battle Angel Alita;

- Ecchi - („nieprzyzwoity”) do określenia sytuacji o mniejszym lub większym zabarwieniu erotycznym, niekoniecznie będących pornografią, np. Chobits;

- Hentai (erotyczny) - tytuł pornograficzny. Termin powszechny na Zachodzie, w Japonii używany wyłącznie w odniesieniu do osób, np. Miłość krok po kroku;

- $\quad Y a o i$ - fabuła koncentruje się na homoseksualnych męskich związkach, zawiera sceny erotyczne (lub tytuły wprost pornograficzne), np. Wild Rock;

${ }^{30}$ M. Jaworski, dz. cyt., s. 124.

${ }^{31}$ G. Rosiński, Komiks musi być ponadczasowy i „bez granic”, rozm. przepr. J. Czarkowska, „Wydawca” 2000, nr 12, s. 8.

32 B. Kurc, Komiks - opowiadanie obrazem, Łódź 2003, s. 78-82. 
- Shounen-ai - tytuły o męskich związkach homoseksulanych bez elementów erotyki;

- $\quad$ Yuri - gatunek przedstawiający związki lesbijskie oparty na seksualności;

- Shoujo-ai - przedstawia związki lesbijskie, tytuły oparte na romantycznym uczuciu.

Zaprezentowany powyżej podział jest jednym z wielu i nie obejmuje całej możliwej tematyki.

\section{Manga poza granicami Japonii oraz jej rozwój w Polsce}

Ekspansja mangi poza Japonię odbywała się stopniowo od końca lat 70. XX w. Pierwsze jednak za granicą pojawiło się anime. Od lat 60. amerykańskie sieci kablowe kupowały wiele japońskich produkcji animowanych, kierując się ich niską ceną. Manga w Ameryce osiągnęła sukces handlowy dopiero w roku 1986, kiedy wydano Lone Wolf and Cub.

Również w Europie filmy animowane wyprzedziły mangę. Angielscy wydawcy celowali w rynek kaset wideo, natomiast francuscy skupili się na serialach telewizyjnych, mimo że podlegały one cenzurze. Również tutaj decydującym czynnikiem była cena ${ }^{33}$. Szacuje się, że we Francji na dzień dzisiejszy około $40 \%$ rynku komiksowego to rynek mangi ${ }^{34}$.

W Polsce, analogicznie do sytuacji w Europie i Ameryce, pierwsze pojawiło się anime. Do polskich kin w 1972 r. trafił film Kot w butach w reżyserii Kimio Yabukiego, wyprodukowany przez Toei Animation w 1969 r. $^{35}$ Wiele popularnych i rozpoznawalnych serii jest produkcji japońskiej, ale świadomość tego jest nadal niska. Są to m.in. Pszczółka Maja, Sindbad czy Muminki.

W Polsce komiks jako gatunek znano już od lat 30. XX w. Był kierowany do dzieci lub służył jako dzieło humorystyczne. Różnił się od tytułów zachodnich, ponieważ początkowo tekst był oddzielony od ob-

33 A. Czaplińska, dz. cyt., s. 2-3.

${ }^{34}$ M. Horodniczy, R. Tichy, Nie-zła sztuka dla chłopaków: wywiad z Tomaszem Kołodziejczakiem, „Fronda”, 2007, nr 42, s. 170.

35 M. Jaworski, dz. cyt., s. 125. 
razka $^{36}$. Po II wojnie światowej komiks w większości tępiono jako „wytwór wrogiej ideologii". Zaczęto tworzyć serie inspirowane popularnymi serialami telewizyjnymi, np. Kapitan Kloss, Janosik. W latach 70. nastąpiło pewne otwarcie na Zachód. Pojawiły się wówczas bardziej rzetelne informacje o komiksach zachodnich, pirackie przedruki prac amerykańskich i francuskich oraz wzorowane na nich historyjki realizowane przez Polaków. W latach 80. komiks zaczął znikać z polskiego rynku. Przestał ukazywać się „Relax”, został też zakończony serial milicyjny opowiadający o przygodach kapitana Żbika. Inne tytuły były wydawane rzadko i nieregularnie ${ }^{37}$. Dopiero po przemianach społeczno-politycznych w roku 1989 pojawiła się możliwość faktycznego poznania komiksowej twórczości zagranicznej, która wpłynęła na rozwój rynku komiksowego.

Zainteresowanie tematyką mangi i anime w Polsce datuje się na połowę lat 90., kiedy to w stacji telewizyjnej Polsat zaczęła ukazywać się Czarodziejka z Księżyca. Wcześniej zainteresowanie tym zagadnieniem było raczej znikome. Fandom (rozumiany jako społeczność fanów) nie istniał, dopiero popularność tego serialu doprowadziła do prawdziwego „boomu” na wszystko, co japońskie. Emisja innych japońskich animacji, takich jak Pokemony, Dragon Ball itd., umocniła pozycję tej tematyki i spowodowała rozwinięcie się fandomu. W poniższej tabeli zamieszczono chronologiczną listę wydawnictw zajmujących się publikacją mang w Polsce.

Tabela 1. Wydawnictwa mangi w Polsce. Stan na luty 2013 r. $^{38}$

\begin{tabular}{|l|c|c|c|}
\hline \multicolumn{1}{|c|}{ Wydawnictwo } & Data powstania & Data zamknięcia & Liczba tytułów \\
\hline JPF & 1996 & & 41 \\
\hline TM-Semic & 1998 & $2000 / 2001$ & 3 \\
\hline Waneko & 1999 & & 30 \\
\hline Mangaya & 1999 & 2000 & 1 \\
\hline Egmont & 2002 & & 14 \\
\hline Kasen & 2002 & $2008 / 2009$ & $16(7)$ \\
\hline
\end{tabular}

${ }^{36}$ A. Stasińska, Komiks - sztuka niedoceniona, „Tygiel Kultury” 2006, nr 7-9, s. 170.

37 J. Szyłak, Komiks, Kraków 2000, s. 167-168.

38 Kolumna „Liczba tytułów” zawiera liczbę mang opublikowanych przez dane wydawnictwo, w nawiasie podano liczbę mang autorstwa Polaków. 
Tabela 1. Wydawnictwa mangi w Polsce (cd.)

\begin{tabular}{|l|c|c|c|}
\hline \multicolumn{1}{|c|}{ Wydawnictwo } & Data powstania & Data zamknięcia & Liczba tytułów \\
\hline Saisha & 2003 & 2005 & 2 \\
\hline Arashi & 2004 & 2004 & 1 \\
\hline Mandragora & 2005 & 2007 & 6 \\
\hline Hanami & 2006 & & 30 \\
\hline Studio JG & 2006 & & $31(19)$ \\
\hline Yumegari & 2012 & & $4(1)$ \\
\hline
\end{tabular}

Źródło: opracowanie własne.

Pierwsze wydawnictwo w naszym kraju zajmujące się publikacją mangi to Japonica Polonica Fantastica (dalej: JPF), które powstało w 1996 r. w Olecku ${ }^{39}$. Jego założycielem jest Shin Yasuda, a debiutanckim tytułem Aż do nieba Riyoko Ikedy. W 1997 r. oficyna ruszyła z drugą pozycją, Sailor Moon - Czarodziejka z Księżyca Naoko Takeuchi. Publikacja pierwszego tomu zbiegła się w czasie z powstaniem dwóch czasopism poświęconych japońskiemu komiksowi i animacji: „Kawaii” pod redakcją Pawła Musiałowskiego, zwanego 'Mr Jedi' (redaktor naczelny do 2003 r.), oraz „Animegaido” prowadzone przez Roberta Korzeniowskiego 'Mr Roota'. JPF do dziś jest największym wydawnictwem, a jego tytuły cieszą się popularnością wśród fanów, m.in. Naruto, Bleach itd.

W 1998 r. wydawaniem mang zajęło się wydawnictwo TM-Semic. Trwało to jednak krótko, publikacje tej oficyny odznaczały się kiepskim wydaniem i słabym tłumaczeniem. Rok później powstało Waneko ${ }^{40}$. Jego założycielami było małżeństwo - Aleksandra i Kenichiro Watanuki oraz Marta Taniguchi. Wydawnictwo zadebiutowało na rynku dziełem Cześć Michael. Działa prężnie do dziś, charakteryzuje się bardzo dobrym kontaktem z czytelnikami. Wydało wiele wyjątkowych dzieł, jak Hiroszima 1945. Bosonogi Gen Keiji Nakazawy, ale także tytuły popularne, jak Kuro-

39 Oficjalna witryna wydawnictwa J. P. Fantastica [on-line] [dostęp 31 marca 2013]. Dostępny w World Wide Web: http://jpf.com.pl/.

40 Wydawnictwo Waneko [on-line] [dostęp 31 marca 2013]. Dostępny w World Wide Web: http://waneko.pl/?page_id=10. 
shitsuji czy Vampire Knight. W tym samym czasie powstało wydawnictwo Mangaya, które wydało tylko jeden tytuł - Cat girl Nuku Nuku. Niedługo później, w 2002 r., wydawaniem komiksu japońskiego zajęła się także oficyna Egmont ${ }^{41}$. Jej publikacje w owym czasie miały wyższą cenę niż w pozostałych wydawnictwach, były wydawane na niezbyt odpowiadającym czytelnikom papierze, a błędy w tłumaczeniach stanowiły normę. W chwili obecnej firma ta wycofuje się powoli z rynku mangowego.

W latach 2002-2004 powstały jeszcze trzy wydawnictwa, które nie dotrwały do dnia dzisiejszego: Kasen, Saisha i Arashi. Pierwsze z nich oprócz tytułów japońskich wydawało także koreańskie manhwy (koreańska odmiana mangi) oraz jako pierwsze zajęło się publikacją polskich mang, które jednak nie zyskały zbytniej popularności. Natomiast Saisha zakończyło działalność tylko na jednym tytule, a Arashi na dwóch.

Oficyny, które utrzymały się na rynku do dziś, powstały dopiero w 2006 r. Studio JG ${ }^{42}$, które wystartowało w sierpniu tego roku z nowymi czasopismami „Otaku”, i Hanami ${ }^{43}$, wydające książki tematycznie związane z Japonią. Oba zajęły się z czasem również produkcją mang. Magazyn „Otaku” był pierwszą publikacją periodyczną po przerwie spowodowanej upadkiem „Kawaii” i „Anime+”. Jego założycielami są Jan „Yanek” Godwod oraz Katarzyna „Naq” Bogdan ${ }^{44}$. Wywodzą się oni z pierwotnego fandomu mangi w Polsce, więc cechuje ich bardzo dobry kontakt z czytelnikami. Studio JG, podobnie jak Kasen, podjęło się wydawania polskich mang, jednak obecnie wydaje tylko tytuły tworzone przez Japończyków. Hanami zajęło się natomiast publikacjami dla starszego i bardziej dojrzałego czytelnika.

Rynek mangi w Polsce, choć nie bez kłopotów, rozwijał się sukcesywnie, oferta kierowana do czytelnika wzbogacała się. Nastąpił wzrost zainteresowania mangą związany z otwarciem Polski na świat, rozwojem Internetu i nowoczesnych technologii.

${ }^{41}$ Wydawnictwo Egmont [on-line] [dostęp 31 marca 2013]. Dostępny w World Wide Web: http://www.egmont.pl/pl/o_wydawnictwie/firma/.

42 Studio JG - oficjalna strona wydawnictwa [on-line] [dostęp 31 marca 2013]. Dostępny w World Wide Web: http://studiojg.pl/about.html.

${ }^{43}$ Wydawnictwo Hanami [on-line] [dostęp 31 marca 2013]. Dostępny w World Wide Web: http://www.wydawnictwo.hanami.pl/.

${ }^{44}$ J. 'Yanek' Godwod, Wywiad z Janem „Yankiem” Godwodem, rozm. K. 'Grisznak' Wojdyło [on-line]. Tanuki.pl [dostęp 31 marca 2013]. Dostępny w World Wide Web: http:// czytelnia.tanuki.pl/lista/pokaz.php/2127/0/. 


\section{Problemy rynku mangi w Polsce}

Firmy specjalizujące się w wydawaniu komiksów muszą mierzyć się ze szczególnymi przeciwnościami. Główną przyczyną problemów rynku mangi w Polsce jest jego wielkość. Można zaryzykować stwierdzenie, że jest to gatunek niszowy, mimo że od momentu pojawienia się w Polsce znacznie się rozwinął. Wiele wydawnictw nie dotrwało do dziś, a te, które się utrzymały, wzmocniły swoją pozycję. Nakłady mang w Polsce, w porównaniu m.in. z rynkiem francuskim czy niemieckim, są niskie. Za bestseller była uważana seria Love Hina wydawnictwa Waneko, która osiągnęła nakład 3 tys. egzemplarzy, podczas gdy m.in. w Rosji nakład tej pozycji osiągnął poziom 10 tys.$^{45}$ Wysokość nakładów jest przyczyną problemów w trakcie negocjacji dotyczących praw autorskich z japońskimi wydawcami. Rynek polski nie jest uznawany za opłacalny, ponieważ uzyskana prowizja za liczbę sprzedanych egzemplarzy - przy tak niskich nakładach - nie jest dla Japończyków atrakcyjna ${ }^{46}$. Ponadto przy długich seriach zdarzają się spadki popularności wśród czytelników, więc aby nie ponosić strat, wydawnictwa są zmuszone ostrożnie dobierać tytuły. Jak wypowiedział się w 2009 r. właściciel Studia JG, J. Godwod: „polski rynek jest zamknięty, niechętny na zmiany i bardzo trwały w swoich przekonaniach" ${ }^{47}$.

Jednym z najważniejszych problemów, z jakimi zmagają się oficyny, jest również ogromny zasób danych dostępnych w Internecie. Od momentu jego upowszechnienia duża część fanów „przeniosła się” do sieci. Popularne jest czytanie „skanlacji” - zeskanowanych amerykańskich wydań mang lub oryginalnych prac japońskich, przetłumaczonych przez fanów i umieszczonych na specjalnych stronach im poświęconych. Wiele tytułów jest dostępnych w sieci bez ograniczeń, co często skutkuje spadkiem sprzedaży. Polscy fani także zajmują się tłumaczeniami, więc do dyspozycji zainteresowanych czytelników jest też pokaźna liczba tytułów w języku polskim. Należy jednak zwrócić uwagę, że gdy wydawnictwo nabywa licencję na dany tytuł, to jego wersja darmowa w sieci

45 T. Nowak, Obrazkowe historie od kuchni, „Print Publishing” 2007, z. 120, s. 20.

${ }^{46}$ J. Górecka, Nie taka manga straszna..., „Wydawca” 2002, nr 1, s. 18-23.

47 Shomei, 3 lata Otaku, „Otaku” 2009, nr 7 (20), s. 5. 
jest usuwana bądź blokowana przez samych autorów tłumaczeń, co w pozostałych krajach jest rzadko praktykowane.

Czytelnicy komiksu japońskiego w Polsce są niezwykle wymagający, czego dowodzą wypowiedzi dotyczące tłumaczeń. Jedni narzekają na zbyt dokładny przekład, uważając, że lepiej pewne pojęcia, tytuły czy imiona pozostawić w wersji oryginalnej. Przykładem tego jest przyrostek „-chan”, który dodany do imienia postaci, może oznaczać m.in. zdrobnienie. Niektórzy czytelnicy wolą wersję oryginalną z przyrostkiem, np. Sakura-chan, natomiast drudzy formę przetłumaczoną, np. Sakurka (przykład z mangi Naruto). Dla tłumaczy trudnym zadaniem są np. onomatopeje. Niektóre funkcjonujące w Japonii nie mają polskich odpowiedników ${ }^{48}$. Przykładem pracy trudnej do przełożenia na język polski jest Appleseed Masume Shirowa wydawnictwa TM-Semic. Tytuł słynie z bogatej terminologii i pojęć technicznych, a translatorzy dokładali starań, by jak najwierniej przełożyć wszystkie pojęcia ${ }^{49}$.

Kolejną przeszkodę w rozwoju rynku mangi stanowią dystrybutorzy. Większość wydawnictw współpracuje z dwiema największymi sieciami księgarskimi, jakimi są Matras i Empik. Jednak narzucona przez nie marża jest nieproporcjonalnie duża do jednocześnie słabej promocji i niewystarczającej widoczności produktów w salonach. Publikacje dotyczące mangi i anime są umieszczane w dziale literatury dziecięcej lub prasy kobiecej. Komiksy japońskie nie są także promowane w gazetkach reklamowych tych sieci. Problemem stały się też opóźnienia w opłatach za sprzedany towar przez Empik. Powoduje to liczne trudności, zwłaszcza dla małych wydawnictw, a do takich należą polskie wydawnictwa mangi. Na początku wprowadzania mangi na nasz rynek jako kanał dystrybucji wykorzystywano również kioski, ale ten sposób rozpowszechniania nie znalazł zwolenników. Było to teoretycznie bardzo wygodne dla czytelników, jednak znalezienie danego tytułu mangowego wśród wszystkich czasopism stało się niemal niemożliwe, a przekonanie sprzedawców do wyeksponowania pozycji zbyt trudne ${ }^{50}$. W chwili obecnej bardzo prężnie działa dystrybucja internetowa. Dzięki niej można pominąć pośredników

48 R. „Kabura” Rzepka, Wywiad z Rafałem „Kabura” Rzepką, rozm. P. 'Mr Jedi' Musiałowski, „Kawaii” 1999, nr 6 (22), s. 51.

49 Adaptacja mangi po polsku, rozm. P. 'Mr Jedi' Musiałowski i T. 'Mr Gato' Gawroński, „Kawaii” 1998, nr 8 (8), s. 58-59.

${ }^{50}$ Mizuniak, Kiosk - niekończąca się bitwa, „MangaMix” 2002, nr 8 (5), s. 103. 
i bezpośrednio uzyskać fundusze na dalsze tytuły, bez niepotrzebnych opóźnień.

Niemalże każde wydawnictwo posiada swój sklep internetowy, często sprzedający również mangi pozostałych oficyn. Studio JG poszło o krok dalej i stworzyło sklep Yatta.pl i zajęło się również sprzedażą różnorodnych gadżetów o tematyce mangi i anime, a także sprowadzaniem na specjalne zamówienie takich produktów z Japonii i innych krajów. W chwili obecnej Yatta.pl jest największym polskim sklepem internetowym poświęconym tego typu produktom ${ }^{51}$.

Kolejnym problemem hamującym rozwój naszego rynku są rosnące ceny. W ostatnich latach nastąpił wzrost cen na całym rynku wydawniczym, co było związane m.in. z podniesieniem stawki VAT do 5\%. Dla porównania pierwszy tom mangi Naruto z 2003 r. kosztował 14,95 zł, a jeden z najnowszych numerów w cyklu - 56, z października 2012 r., można nabyć już za 18,90 zł. W chwili obecnej cena większości wydawanych tytułów oscyluje w granicach 19-20 zł, co nie jest małą kwotą, gdy ktoś decyduje się na kompletowanie kilku serii jednocześnie. Powraca w tym miejscu również problem skanlacji. Ponieważ znajomość angielskiego wśród pokolenia interesującego się mangą jest powszechna, część czytelników z oszczędności woli przeczytać dany tytuł po angielsku, ale za darmo.

Kłopot stanowią także tzw. empikowi czytacze, czyli osoby, które czytają dany tytuł w księgarni, ale go nie kupują. Podobnie jest w przypadku książek, ale ze względu na czas, jaki trzeba poświęcić na lekturę, głównymi ofiarami stały się czasopisma i mangi. W związku z tym komiksy znajdujące się w księgarniach często bywają uszkodzone.

Pewną poważną barierę stanowi też opinia, jaką mają mangi w Polsce. Nadal mocno zakorzeniony jest pogląd, że komiksy są gatunkiem dla dzieci. Z tego powodu komiks japoński jest oskarżany o rozprzestrzenianie treści nieodpowiednich dla tej grupy odbiorców. Tymczasem na naszym rynku jest niewiele tytułów przeznaczonych dla najmłodszych czytelników. Przykładowo, wydawnictwo Waneko, które dotychczas wydało około 30 tytułów, w swojej ofercie ma tylko dwie pozycje dla dzieci.

51 J. Godwod, Re: Pytania dotyczące wydawnictwa [on-line]. Do: M. Ostrowska. 10 marca 2012 r., 12:33 [dostęp 31 marca 2013]. Korespondencja osobista. 
Drugi stereotyp zakłada, że mangi są przesycone brutalnością, przemocą i erotyzmem. Przyczyną takiego postrzegania jest niewątpliwie niewiedza. Przykładowo, rynek francuski jest bardzo bogaty, a wiele japońskich serii prezentuje się w telewizji. Zdarza się jednak, że dystrybutorzy są pozywani do sądu, ponieważ tytuły odbierane jako bajki są emitowane w godzinach powrotów dzieci ze szkół, podczas gdy później okazuje się, że są to horrory lub inne gatunki nieodpowiednie dla widza w tym wieku ${ }^{52}$.

W jednym z artykułów w czasopiśmie „Kawaii” przytoczono najczęstsze zarzuty wobec mangi w Polsce, potwierdzające przywołane powyżej stereotypy. Przede wszystkim padały głosy, że jest to pornografia. Tymczasem tytuły pornograficzne są tylko jednym z bardzo wielu gatunków mang, wśród których można znaleźć przecież także komedie, romanse, horrory itd. Kolejny zarzut to propagowanie przemocy. Istnieją publikacje ukazujące walki, morderstwa itd. w sposób niezwykle brutalny, lecz są one przeznaczone wyłącznie dla dorosłego czytelnika. Nie tylko japońskie produkcje komiksowe czy animowane pokazują walkę dobra ze złem, która przez niektórych jest odbierana właśnie jako propagowanie brutalności. Należy też pamiętać, że manga i anime należą do kultury diametralnie odmiennej od naszej, w której inne tematy i sytuacje odbierane są jako bulwersujące ${ }^{53}$.

Od początku istnienia gatunku jego miłośnicy mogli spotkać się z różnymi (także szokującymi lub niezrozumiałymi dla nich) opiniami na swój temat. Na spotkaniu dotyczącym mangi w Warszawskim Ośrodku Kultury, zorganizowanym 12 stycznia 1998 r. przez miłośników fantastyki, wśród uczestników była rozprowadzana broszurka zawierająca informacje o fanach mangi. W przedrukach z różnych tytułów prasowych nazywa się ich m.in. kolejną sektą, która ma „destrukcyjny wpływ na młodego człowieka, gdyż uzależnia i zmusza do wydawania ostatnich pieniędzy na kolejne gadżety i odcinki komiksów oraz filmów z ulubionymi bohaterami”54.

Głośnym echem wśród fandomu odbiła się sprawa nazwana przez nich „Gołą pupą Bulmy”55. W telewizji 12 lipca 2003 r. został wyemito-

${ }^{52}$ Bazyl \& Blazjusz, Instrukcja obsługi rodziców, czyli jak oglądać anime w Polsce, „Kawaii” 1998, nr 16 (15), s. 58-59.

53 P. Musiałowski 'Mr Jedi', Mangowy survival, „Kawaii” 1999, nr 2-3, s. 48.

54 'Mr Master', Fantastyczna manga, „Kawaii” 1998, nr 8 (8), s. 56-57.

55 A. Czaplińska, dz. cyt., s. 21. 
wany 10-minutowy reportaż potępiający mangę, wskazujący, jaki zły przykład daje ona dzieciom. Zaprezentowano w nim tomik z serii Dragon Ball, w którym bohaterka w jednym z kadrów pokazuje... pupę. Twórcy reportażu udostępnili ten wyżej wymieniony tomik czteroletnim dzieciom, sugerując, że jest dla niech przeznaczony. Nie pomogła wypowiedź polskiego wydawcy, że są to publikacje dla osób powyżej 15. roku życia i jako takie są promowane. Warto zauważyć, że wspomniany reportaż został nadany w stacji TVN, w której w tym samym czasie był emitowany japoński serial animowany oparty na tak „potępianej” przez autorów programu mandze. Członków fandomu zbulwersował niewątpliwy „brak poszanowania innej kultury oraz brak wiedzy i złośliwa jednostronność polskich dziennikarzy"56.

Do dziś w telewizji i w prasie można spotkać się czasami ze specyficzną „nagonką” na fanów tego gatunku. Dzieje się tak ze względu na odmienność prezentowanych standardów kulturowych. Co interesujące, komiksy japońskie są najczęściej atakowane przez stacje uważane za najbardziej „postępowe” ${ }^{57}$.

Ostatnio głośna wśród fanów była sprawa odwołania jednego z konwentów - Love 3, który miał miejsce we Wrocławiu 14 lutego $2012 \mathrm{r}^{58} \mathrm{Im}$ preza odbyła się w mniejszej szkole niż zaplanowano, ponieważ placówka, w której pierwotnie miało odbyć się spotkanie, zerwała nagle współpracę z organizatorami ${ }^{59}$. W wyniku tego wiele osób, które przybyły z całej Polski, z powodu braku miejsc nie dostało się do środka. Problemem stał się także nocleg. Na konwentach popularne są tzw. sleep roomy - są to miejsca, gdzie można rozłożyć śpiwór i przenocować, tę funkcję pełnią zazwyczaj sale gimnastyczne lub klasy. Uczestnicy tego konwentu musieli np. nocować na korytarzach.

Wpływ na zmianę decyzji szkoły miało najprawdopodobniej ukazanie się w „Przewodniku Katolickim” artykułu pt. Armagedon nadchodzi? Magdaleny Guziak-Nowak ${ }^{60}$. Autorka napisała w nim, że nie jest prze-

${ }^{56}$ Dżordż, Uwaga! Tania sensacja!, „Kawaii” nr 2003, nr 5 (45), s. 58-60.

57 Tamże.

58 Dyrektorzy vs konwentowicze [on-line]. Anime on-line [dostęp 31 marca 2013]. Dostępny w World Wide Web: http://www.anime-shinden.info/16644-dyrektorzy-vskonwentowicze.html.

59 Tamże.

${ }^{60}$ M. Guziak-Nowak, «Armagedon nadchodzi»?, „Przewodnik Katolicki” [on-line] 
ciwniczką mangi, jeśli trafia ona do odpowiednich odbiorców. Zarzuciła polskim wydawcom jej nieodpowiednie oznakowanie. Zaprezentowała również swoją wizję konwentów: „Warsztaty z szycia pluszaków, kuchnia azjatycka, Japan Quiz, a w sali obok panele dla «fanów psychopatów i ich wąskich źrenic» oraz «praktyczne konkursy», w których nastoletnie dziewczyny udają lesbijki, a chłopcy homoseksualistów. I to wszystko w naszych szkołach"61.

Organizatorzy konwentu zapewniali, że nie ma w programie atrakcji przeznaczonych dla osób powyżej 18. roku życia, ponieważ zdają sobie sprawę, że często na konwent przyjeżdżają całe rodziny. W przypadku innych spotkań takie atrakcje, jak pokazy filmów hentai bądź yaoi, są odpowiednio oznakowane i sprawdza się wiek uczestników. Każda osoba niepełnoletnia musi także okazać przed otrzymaniem wejściówki podpisaną zgodę od rodziców. W związku z tą sprawą został opublikowany artykuł Pokedemony! Manga i anime nie w naszej szkole na stronie Gazeta. pl napisany przez Olgę Szponar ${ }^{62}$. Sprawa nabrała szybko ogólnopolskiego wymiaru, ponieważ Kuratorium Oświaty zaczęło domagać się, by prokuratura zbadała sprawę konwentów mangi i anime. Przedstawiciel Kuratorium tłumaczył, że „tak samo jak nie można wynajmować szkół na imprezy zakrapiane alkoholem, tak samo nie powinno się ich wynajmować na spotkania, w których dochodzi do głosu erotyka"63. Organizatorzy konwentów we wszystkich tych artykułach byli oskarżani o propagowanie homoseksualizmu oraz satanizmu. Odwoływanie konwentów z różnych powodów zdarzało się od początku ich istnienia, jednak skala tego zjawiska nadal rośnie. Od stycznia do października 2012 r. odwołano blisko jedenaście konwentów o tematyce związanej z japońską kulturą. Paweł Musiałowski nakręcił autorski filmik o tej sprawie, w którym m.in. rozmawiał z twórczynią konwentu Love 3 . Zamieścił go na swoim blogu Japonia oczami fana. Zaznaczył, że taka sytuacja trwa od połowy lat 90.,

2012, nr 5 [dostęp 31 marca 2013]. Dostępny w World Wide Web: http://www.przewodnik-katolicki.pl/nr/spoleczenstwo/quotarmagedon_nadchodziquot.html.

61 Tamże.

${ }^{62}$ O. Szponar, Pokedemony! Manga i anime nie w naszej szkole. Gazeta.pl [on-line] z dnia 25 lutego 2012 [dostęp 31 marca 2013]. Dostępny w World Wide Web: http:// krakow.gazeta.pl/krakow/1,35803,11233833,Pokedemony_Manga_i_anime_nie_w_naszej_szkole.html.

${ }^{63}$ Tamże. 
odkąd pojawiła się manga i anime w Polsce. Jego zdaniem przeciwnikami mangi są radykalni katolicy, którzy widzą w japońskiej popkulturze złe wpływy i przekonują o konieczności ratowania dzieci „ze szpon magii i okultyzmu". Dodatkowo organizatorzy konwentów ponieśli straty materialne oraz musieli udowadniać swoją niewinność, mimo usunięcia kontrowersyjnych atrakcji ${ }^{64}$.

Wielbiciele gatunku wypowiadają się na forach internetowych, uskarżając się na brak zrozumienia. Panuje powszechne mniemanie, że komiksy to nośniki dla dzieci. Tymczasem pierwsza grupa odbiorców, która obserwowała początki mangi w Polsce, zdążyła już dorosnąć. Część osób straciła zainteresowanie, część nadal kontynuuje swoje hobby, często już bardziej świadomie. Takim przykładem jest twórca Studia JG Jan Godwod, który wywodzi się z fandomu, a swoje zainteresowania wykorzystał do stworzenia wydawnictwa i sklepu internetowego.

Zupełnie inaczej jest postrzegana manga w Japonii, gdzie w $2000 \mathrm{r}$. Japońskie Ministerstwo Edukacji w jednym z rozporządzeń uznało mangę i anime za ,jedną z najważniejszych form ekspresji artystycznej w kulturze nowoczesnej Japonii". W dokumencie ministerialnym podkreślano ponadto wartość merytoryczną tych dzieł. Doceniono również ich wymiar artystyczny ${ }^{65}$. Jednak chociaż omawiane wydawnictwa są w Japonii powszechne i ogólnodostępne, także tam bywają oceniane krytycznie i czasem budzą kontrowersje.

Rynek mangi w Polsce jest niewielki, lecz cały czas się rozwija, kontynuowane są wcześniejsze edycje i wydawane nowe tytuły. Udoskonala się tłumaczenia, publikuje się na coraz lepszym papierze. Nie można jednak tego powiedzieć o rynku anime. W chwili obecnej nie ma w Polsce ani jednego dystrybutora, który zajmowałby się ich wydawaniem, nie licząc tytułów studia Ghibli.

W Polsce wyróżnia się pewne okresy zainteresowania tematyką związaną z komiksem japońskim. Począwszy od 1997 r., na fali popularności serialu Czarodziejka z Księżyca, Polacy dowiadywali się dopiero, czym jest manga i anime. Wtedy to pojawiło się gwałtowne zainteresowa-

${ }^{64}$ P. Musiałowski 'Mr Jedi', Konwent Love 3 [on-line]. Japonia oczami fana [dostęp 31 marca 2013]. Dostępny w World Wide Web: http://kawaii-mrjedi.blogspot.com/2012/02/ konwent-love-3.html.

${ }^{65}$ Manga uznana za sztukę!, „Kawaii” 2001, nr 1 (29), s. 9. 
nie tematem ze względu na prezentowaną egzotykę. Powstawały liczne czasopisma, kluby mangowe, organizowano wiele konwentów. Gdy na przełomie nowego tysiąclecia stacje telewizyjne zaczęły wycofywać się z emisji popularnych anime i przestały wprowadzać nowe tytuły, spowodowało to pewną recesję na tym polu. Słabsze wydawnictwa upadły, utrzymały się tylko największe oficyny. Przestały również ukazywać się czasopisma mangowe. Nadal w całym kraju były jednak organizowane konwenty i spotkania, ale to zjawisko nie osiągnęło już takiej skali jak poprzednio.

Po lekkim kryzysie tego gatunku w latach 2000-2009 obecnie można zaobserwować pewien powrót popularności mangi w Polsce, lecz przebiega on w odmienny sposób niż poprzednio. Głównym nośnikiem informacji stał się Internet. Tam fani dyskutują ze sobą na różne tematy, korzystają z literatury przedmiotu, a nawet czytają mangi w wersji elektronicznej. Ponowne zainteresowania potwierdzają m.in. rozwijające się sklepy „z gadżetami”, jak wspomniany już Yatta.pl, ale także Manganime. pl, Manga-city.pl czy Aniushop.com.pl. Pojawiły się również, niedługo po „Otaku”, inne czasopisma, takie jak „Kyaa”, „Arigato”, „Visual Scene”.

\section{Podsumowanie}

Nie sposób nie zauważyć, jak wiele kontrowersji wywołuje manga. Ma ona wielu zagorzałych zwolenników, ale także przeciwników. Niemniej jednak jest obecna w Polsce już od 16 lat. Przybyła na fali popularności anime w telewizji i od razu spowodowała ogromne „zamieszanie”. Przyniosła ze sobą modę na wszystko, co japońskie i orientalne, zaczęły powstawać czasopisma zajmujące się tą tematyką i liczne wydawnictwa, a na spotkania miłośników gatunku przybywały tysiące osób z całego kraju.

Polski rynek jest mały, nic jednak nie wskazuje na to, by miał upaść bądź przechodzić kolejny kryzys. Planowane są nowe, oczekiwane wśród miłośników gatunku tytuły, które z pewnością podtrzymają zainteresowanie mangą w Polsce. 


\section{The manga market in Poland}

ABSTRACT: Manga graphic novels have been present on Polish publishing market since 1997. The first publisher in Poland to start printing manga comic books was J. P. Fantastica. Today it is the largest and most important Polish publishing house printing manga, with four others in the market. The first manga magazine was "Kawaii" edited by Paweł Musiałowski. Manga is still controversial in Poland which causes problems for the publishing market such as distribution and technological issues, common stereotypes and difficulties in obtaining a license.

KEYWORDS: comics, manga, publishing market. 